\title{
Cone Beam Computed Tomography for Evaluation of Impacted Supernumerary Teeth. A case report.
}

\author{
Tomografía Computarizada con haz de cono para Evaluación de Dientes \\ Supernumerarios Impactados. Reporte de Caso.
}

\author{
Ahmed Fathi AL-Omar ${ }^{1}$ \& Usama Abd El Raouf El Dakrory².
}

AL-Omar, A.F. \& El Raouf El Dakrory, U.A. Cone Beam Computed Tomography for Evaluation of Impacted Supernumerary Teeth. A case report. Int. J. Med. Surg. Sci., 4(4):1238-1240, 2017.

SUMMARY: Supernumerary paramolars are the rare anomalies of the maxillofacial complex. These are more common in the maxilla than in the mandible. Supernumerary teeth are an infrequent developmental alteration that can appear in any area of the dental arches and which are often associated with several syndromes such as cleidocranial dysplasia or Gardner syndrome. Multiple supernumerary teeth in individuals with no other associated diseases or syndromes are very uncommon. Objective: To evaluate the value of cone-beam CT (CBCT) in the diagnosis and orientation of supernumerary teeth in the dental arches. Treatment: After taking a cone beam computed tomograph (CBCT), surgical extraction was performed under local anaesthesia. Conclusion: The position of the supernumerary teeth is varied in the maxilla, and often causes permanent dentition complications. CBCT imaging yields accurate 3-dimensional pictures of supernumerary teeth, local dental and bony structures, which is helpful for diagnosis and orientation of supernumerary teeth. Cone beam computed tomography is crucial for exact localization, for treatment planning, and for the surgical approach in cases of multiple supernumerary teeth.

KEYWORDS: cone beam computed tomography; CBCT; supernumerary teeth.

\section{INTRODUCTION}

Supernumerary teeth are defined as those in addition to the normal series of deciduous or permanent dentition. They may occur anywhere in the mouth. They may appear as a single tooth or multiple teeth, unilaterally or bilaterally, erupted or impacted and in mandible/maxilla or both the jaws. The prevalence of supernumerary teeth varies between 0.1 and $3.8 \%$ and is more common in the permanent dentition. (Yusof, 1990; Rajab \& Hamdan, 2002; Brook, 1974) The low prevalence of supernumerary teeth in primary dentition is because it is generally overlooked by the parents, is often of normal shape (supplemental type), erupt normally, and appear to be in proper alignment. (Scheiner \& Sampson, 1997) Supernumerary teeth in the absence of syndromes such as cleidocranial dysplasia or Gardner's is a rare event.

The most common supernumerary tooth is the mesiodens which appears in the maxillary midline. The exact etiology of supernumerary teeth is unclear but many theories exist in an attempt to explain why extra teeth are present in some individuals. Supernumerary teeth show strong association with developmental disorders such as cleft lip and palate, cleidocranial dysostosis, Gardener syndrome and less commonly with Ehlers-Danlos syndrome, Fabry Anderson's syndrome, chondroectodermal dysplasia. (Rajab \& Hamdan; Grimanis et al., 1991)

Supernumerary teeth are classified according to morphology and location. Impacted supernumerary teeth may present as asymptomatic but can cause a plethora of clinical problems including, but not limited to: failure of eruption of teeth, displaced eruption of teeth, crowding, root resorption, cyst formation, incomplete space closure during orthodontic treatment and They may also interfere in alveolar bone grafting and implant placement. (Brauer, 2010; Walker et al., 2005; Garvey et al., 1999)The incidence is considerably higher in the maxillary incisor region followed by maxillary third molar and mandibular molar, premolar, canine and lateral incisors.(Grimanis et al.)Though there is no significant sex distribution

\footnotetext{
1. Assistant Consultant Department Of Oral and Maxillofacial Surgery King Khalid University Hospital, Dental University Hospital Faculty of Dentistry, King Saud University, Saudi Arabia.

2. Lecturer of Oral and Maxillofacial Surgery, Faculty of Oral and Dental Medicine, Misr University of science and technology.
} 
in primary supernumerary teeth, males are affected approximately twice than females in the permanent dentition. (Garvey et al.; Kinirons, 1982)

When supernumerary teeth are discovered and orthodontics employed, a decision regarding the fate of supernumerary teeth must be made. An important part of the decision process is determining the precise location of the supernumerary teeth. Because supernumerary teeth can cause delayed/ impeded eruption of teeth, root resorption, and/or inability to properly orthodontically move teeth into proper position, most supernumerary teeth should be removed prior to orthodontic treatment. (Brauer; Garvey et al.) Prior to the development of three dimensional Cone Beam Computed Tomography (CBCT), determining the exact location of impacted supernumerary teeth could be approximated with multiple $x$-rays from different angles.

Distortion, projectional effects, and superimposition of adjacent structures often makes precise localization on the intended tooth difficult. (Brauer) CBCT has been shown to provide superior three dimensional imaging to "plain films" and provide the doctor with precise anatomic truth in determining the location of impacted teeth. (Brauer; Walker et al.)

\section{CASE REPORT}

The patient was referred to the Outpatient Clinic of Oral Surgery Department, Faculty of Oral and Dental Medicine, Cairo University from the Orthodontist Department for evaluation and treatment of impacted wisdom teeth as well as impacted supernumerary teeth in the left maxilla and mandible.

Evaluation of the Panorex (Fig 1) shows supernumerary impacted teeth. Due to the inability to palpate either and the close proximity of these teeth to adjacent teeth and vital structures, a CBCT was ordered. Examination of the images from the CBCT shows the palatal location of tooth. (Fig 2)

After discussion of the CBCT findings with the patient and parent, informed consent was obtained for extraction of the supernumerary teeth. Palatal approach was used to access and extract the supernumerary teeth (Fig 3).

Extraction should be performed carefully to prevent damage to adjacent permanent teeth. The clinician should be careful to avoid complications such as damaging nerve and blood vessels during manipulation of the tooth, perforation of maxillary sinus, pterygomaxillary space, orbit and fracture of maxillary tuberosity.

Fig. 1. Panoramic view howing the supernumerary impacted teeth.

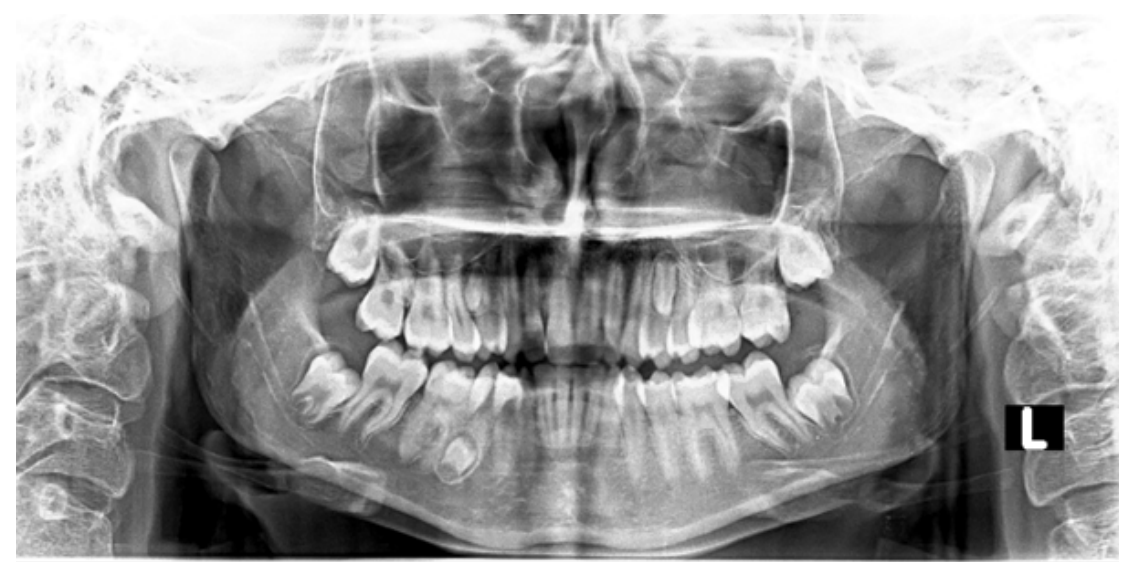

Fig. 2. Examination of the images from the CBCT shows the palatal location of tooth.

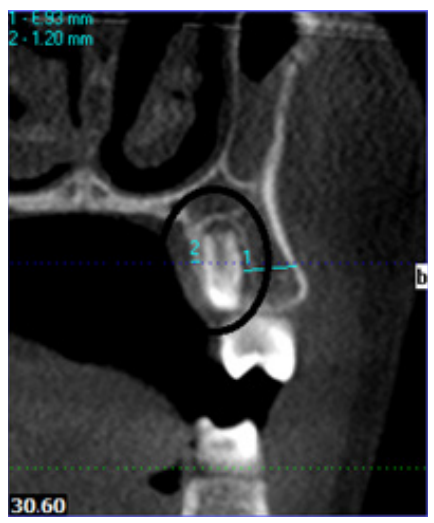

Fig. 3. Palatal approach for extract the supernumerary teeth.

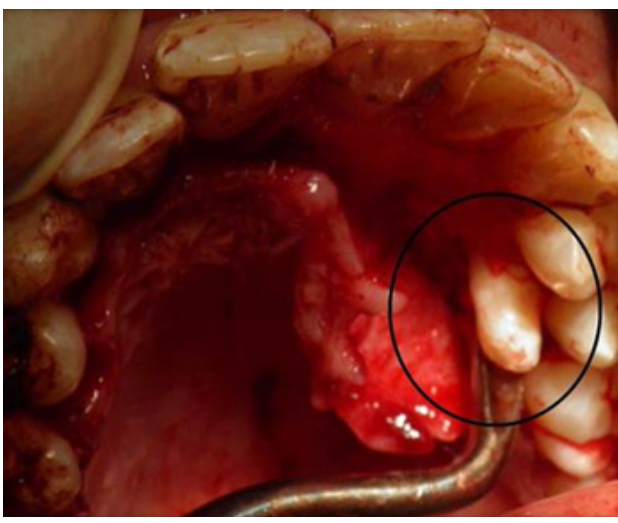


AL-Omar, A. F. \& El Raouf El Dakrory, U.A. Cone Beam Computed Tomography for Evaluation of Impacted Supernumerary Teeth. A case report. Int. J. Med. Surg. Sci., 4(4):1238-1240, 2017.

\section{DISCUSSION}

Correct surgical-orthodontic management of patients with impacted supernumerary teeth is enhanced by accurate diagnosis and precise localization of any supernumerary teeth. (Yusof) CBCT allows the surgeon and orthodontist to more accurately evaluate the exact location of supernumerary impacted teeth as well as assess their impact on the patient's orthodontic plan. Knowledge of the precise location of the supernumerary impacted teeth provides the surgeon with better diagnostic tools and thus allows him to better determine the risks and benefits of the surgery. This increased knowledge also translates into determination of better surgical approach when extracting the teeth and less risk to the patient.

\section{CONCLUSION}

The position of the supernumerary teeth is varied in the maxilla, and often causes permanent dentition complications. CBCT imaging yields accurate 3-dimensional pictures of supernumerary teeth, local dental and bony structures, which is helpful for diagnosis and orientation of supernumerary teeth. Cone beam computed tomography is crucial for exact localization, for treatment planning, and for the surgical approach in cases of multiple supernumerary teeth.

AL-Omar, A.F. \& El Raouf El Dakrory, U.A. Tomografía Computarizada con haz de cono para Evaluación de Dientes Supernumerarios Impactados. Reporte de caso. Int. J. Med. Surg. Sci., 4(4):1238-1240, 2017.

RESUMEN: Los paramolares supernumerarios son las anomalías raras del complejo maxilofacial. Estos son más comunes en el maxilar que en la mandíbula. Los dientes supernumerarios son una alteración infrecuente del desarrollo que puede aparecer en cualquier área de los arcos dentales y que a menudo se asocian con varios síndromes como la displasia cleidocraneal o el síndrome de Gardner. Múltiples dientes supernumerarios en individuos sin otras enfermedades o síndromes asociados son muy poco comunes. Objetivo: evaluar el valor de la TC con haz de cono (CBCT) en el diagnóstico y la orientación de los dientes supernumerarios en los arcos dentales. Tratamiento: Después de tomar un tomógrafo computarizado con haz cónico (CBCT), la extracción quirúrgica se realizó bajo anestesia local. Conclusión: la posición de los dientes supernumerarios varía en el maxilar y a menudo causa complicaciones permanentes en la dentición. Las imágenes CBCT producen imágenes tridimensionales precisas de dientes supernumerarios, estructuras dentales y óseas locales, lo que es útil para el diagnóstico y la orientación de los dientes supernumerarios. La tomografía computarizada con haz cónico es crucial para la localización exacta, la planificación del tratamiento y el abordaje quirúrgico en casos de múltiples dientes supernumerarios.

PALABRAS CLAVE: Tomografía computarizada de haz cónico; CBCT; dientes supernumerarios.

\section{REFERENCES}

Brauer, H.U. Case Report: Non-syndromic multiple supernumerary teeth localized by cone beam computed tomography. Eur. Arch. Paediatr. Dent.,11(1):41-3, 2010.

Brook, A.H. Dental anomalies of number, form and size: Their prevalence in British school children. J. Int. Assoc. Dent. Child.,5(2):37-53, 1974.

Garvey, M.T., Barry, H.J., \& Blake, M. Supernumerary teeth-An overview of classification, diagnosis, and management. J. Can. Dent. Assoc.,65(11):612-6, 1999.

Grimanis, G.A., Kyriakides, A.T., \& Spyropoulos, N.D. A survey on supernumerary molars. Quintessence Int.,22(12):989-95, 1991.

Kinirons, M.J. Unerupted premaxillary supernumerary teeth. A study of their occurrence in males and females. Br. Dent. J.,153(3):110, 1982.

Rajab, L.D., \& Hamdan, M.A. Supernumerary teeth: Review of the literature and a survey of 152 cases. Int. J. Pediatr. Dent.,12(4):244-54, 2002.
Scheiner, M.A, \& Sampson, W.J. Supernumerary teeth: A review of the literature and four case reports. Aus. Dent. J.,42(3):160-5, 1997.

Walker, L., Enciso, R., \& Mah, J. Three-dimensional localization of maxillary canines with cone-beam computed tomography. Am. J. Orthod. Dentofacial Orthop., 128(4):418-23, 2005.

Yusof, W.Z. Non-syndromal multiple supernumerary teeth: Literature review. J. Can. Dent. Assoc., 56(2):147-9, 1990.

\section{Autor de correspondencia:}

Ahmed Fathi AL-Omar.

Department Of Oral and Maxillofacial Surgery king Khalid University Hospital, Dental University Hospital Faculty of Dentistry, King Saud University.

Tel.: (+96) 6566684840

E-mail: ahmed_alomar@hotmail.com

Conflictos de interés: None.

Financiamiento: None.

Recibido: 25-12-2017

Aceptado: 05-01-2018 